\title{
Genetic variability and differentiation in red deer (Cervus elaphus L) of Central Europe
}

\author{
GB Hartl ${ }^{1 *}, \mathrm{R}$ Willing ${ }^{1}, \mathrm{G}$ Lang $^{2}$, F Klein ${ }^{3}, \mathrm{~J} \mathrm{Köller}^{4}$
}

1 Forschungsinstitut für Wildtierkunde der Veterinärmedizinischen Universität Wien, Savoyenstrasse 1, A-1160 Vienna, Austria;

2 26A, Rue Principale, 67240 Gries;

3 ONC, Centre National d'Etude et de Recherche Appliquée sur les Cervidés-Sangliers, Section Cerf, 8 rue Adolphe Seyboth, 67000 Strasbourg, France;

4 University of Agricultural Sciences, Institute of Zoology and Game Biology Pater Karoly u, 1, H-2103 Gödöllö, Hungary

(Received 25 September 1989; accepted 2 May 1990)

\begin{abstract}
Summary - A total of 365 specimens of red deer (Cervus elaphus L) from France, Hungary and Austria were examined for genetic variability and differentiation at 3443 isoenzyme loci by means of horizontal starch gel electrophoresis and enzyme specific staining procedures. Calculated over 34 loci, mean $\bar{P}$ is $11.4 \%(S D, 2.05 \%)$ and mean $\bar{H}$ is $3.5 \%(S D, 0.8 \%)$. These values are similar to those detected in other studies on red deer. Relative genetic differentiation $\left(G_{S T}\right)$ is $10.4 \%$, but absolute genetic distances are very small throughout the study area, suggesting that all populations belong to the same subspecies ( $C$ e hippelaphus). In populations living in enclosures no general decrease in genetic variability was detected, but some rare alleles may have been lost and allele frequencies seem to be altered by genetic drift. The most ubiquitous polymorphism is that in IDH-2, which, together with other evidence, suggests that it may be maintained by selection. Other common polymorphisms are those in ME-1, ACP-1 and ACP-2, whereas variation in MPI, GPI-1, LDH-2, PGM-2 and SOD-2 shows a scattered distribution. Aspects of local differentiation among populations in France, Hungary and Austria are discussed.
\end{abstract}

red deer / electrophoresis / isoenzymes / genetic variability / genetic distance

Résumé - Variabilité et divergence génétique chez le cerf rouge (Cervus elaphus L) d'Europe. La variabilité électrophorétique de $34-43$ locus enzymatiques a été examinée chez 365 cerfs nobles (Cervus elaphus $L$ ) représentant 17 populations originaires de France, de Hongrie et d'Autriche. Les taux moyens de polymorphisme $(\overline{\mathrm{P}})$ et d'hétérozygotie $(\overline{\mathrm{H}})$ sont respectivement de 11,4\% ( $\pm 2,05 \%)$ et 3,5\% ( $\pm 0,8 \%)$. La différenciation génétique relative moyenne $\left(\mathrm{G}_{\mathrm{ST}}\right)$ est de 10,4\%, mais les distances génétiques absolues sont très faibles sur la région examinée, suggérant ainsi que toutes les populations analysées appartiennent à la même sous-espèce (C elaphus hippelaphus). Aucune réduction notable de diversité génétique n'est observée pour les populations vivant en enclos, mais quelques allèles peu fréquents

* Correspondence and reprints 
ont été perdus par certaines d'entre elles et la fréquence de certains autres allèles semblent avoir été modifiée par la dérive génétique. Le polymorphisme le plus commun est celui d'IDH-2. Le caractère ubiquitaire du polymorphisme observé à l'isoenzyme IDH-2 conforte l'hypothèse, émise à partir d'autres arguments, d'un maintien de ce polymorphisme par sélection. On constate que certains polymorphismes, comme celui de ME-1,ACP-1, ACP2 sont très fréquents, tandis que d'autres comme ceux de MPI, GPI-1, LDH-2, PGM-2 et SOD-2 montrent une distribution plus dispersée. Les aspects de la différenciation locale entre populations françaises, hongroises et autrichiennes sont discutés.

cerf rouge / électrophorèse / isoenzymes / variabilité génétique / distance génétique

\section{INTRODUCTION}

Deer are among the few groups of large mammals which have been extensively studied by electrophoretic multilocus investigations during the last decade to evaluate genetic diversity within and between populations and species (see Hartl and Reimoser, 1988 for review). In red deer (Cervus elaphus L), biochemical genetic studies were carried out mainly in Scottish ( $C$ e scoticus Lönneberg, 1906; Dratch, 1983, Gyllensten et al, 1983; Dratch and Gyllensten, 1985; Pemberton et al, 1988), but also in Swedish ( $C$ e elaphus $\mathrm{L}$ ) and Norwegian ( $C$ e atlanticus Lönneberg, 1906) populations (Gyllensten et al, 1983). Genetic divergence between Scottish and American ( $C$ e canadensis Erxleben, 1777) red deer was examined by Dratch and Gyllensten (1985). Values of polymorphism and average heterozygosity estimated in all these studies are within the range generally observed in mammals (Baccus et al, 1983; Nevo et al, 1984). Population genetic studies in European red deer have also been carried out in Germany and Hungary in demes of the local form $C$ e hippelaphus Erxleben, 1777 (Bergmann, 1976; Kleymann, 1976; Albert, 1984; Bergmann and Moser, 1985; Herzog, 1986; Kabai, 1987; Herzog, 1988a,b). However, due to the small number of loci or to the restricted geographical origin of the individuals examined, no overall values of genetic diversity could be calculated for comparison with the data given on other subspecies in the papers mentioned above.

To obtain a comprehensive picture of biochemical genetic variation and differentiation in red deer of Central Europe and a basis for comparison with other morphological subspecies, we conducted an electrophoretic investigation of 34 to 43 loci in various red deer populations from France, Hungary and Austria, which belong to $C$ e hippelaphus (Wagenknecht, 1986).

\section{MATERIALS AND METHODS}

During the hunting seasons from 1987-1989 liver and kidney from 326 specimens of red deer from France and Hungary were collected by local hunters and frozen to $-20^{\circ} \mathrm{C}$ as soon as possible after death of the animals. In the French specimens samples from heart muscle were also taken. The distribution of sampling sites is shown on the map in fig 1 . Data from 39 Austrian red deer, screened by Hartl (1986a), were also included in this study. Electrophoretic and staining procedures were performed according to routine methods (Hartl and Höger, 1986; Hartl et al, 1988a).

The following isoenzyme systems were investigated (abbreviation; EC number and tissue used are given in parentheses; $\mathrm{L}=$ liver, $\mathrm{K}=$ kidney, $\mathrm{H}=$ heart): sorbitol 


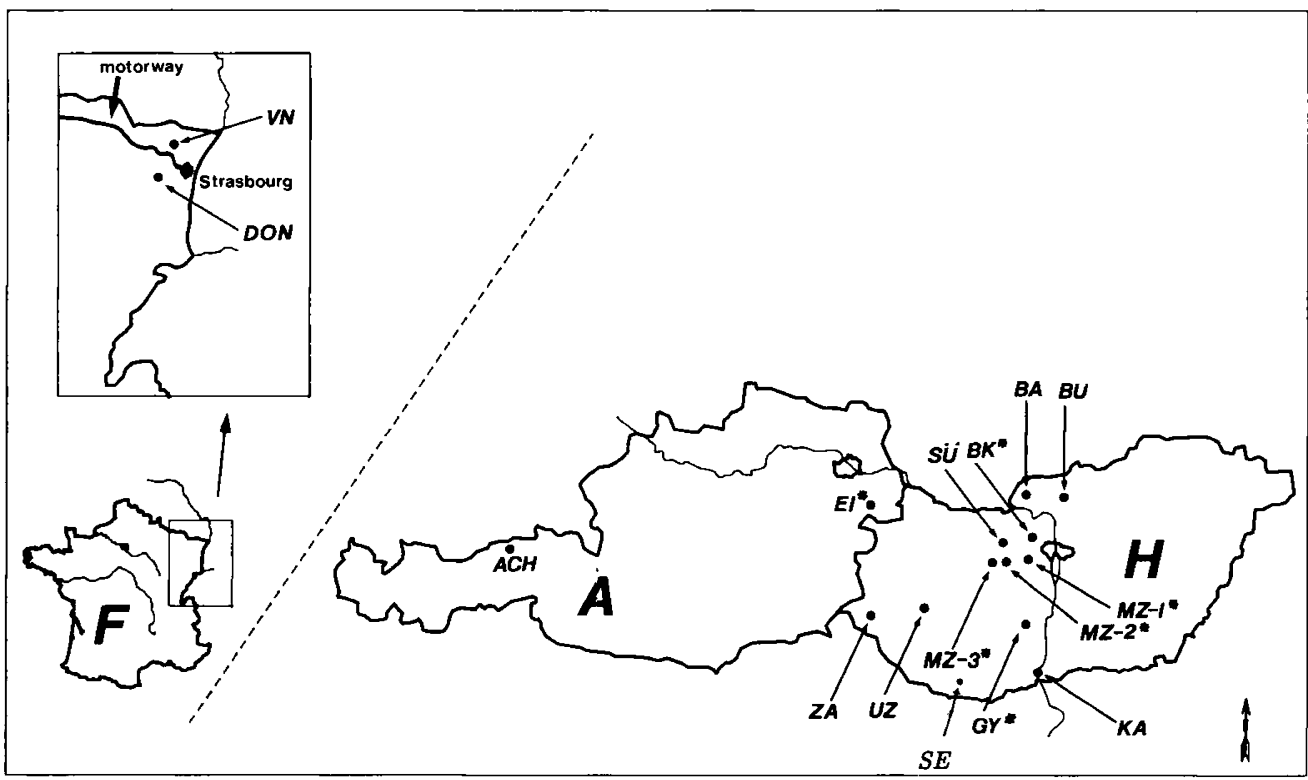

Fig 1. Distribution of sampling sites of red deer in France (F), Austria (A) and Hungary $(\mathrm{H}) .^{*}=$ population in enclosure. $\mathrm{BK}^{*}=$ Budakeszi, $\mathrm{MZ}-1^{*}, \mathrm{MZ}^{*} 2^{*}, \mathrm{MZ}-3^{*}=$ enclosures in the Mezöföld region, $\mathrm{ZA}=\mathrm{Zala}, \mathrm{GY}^{*}=$ Gyulaj, $\mathrm{BA}=$ Balassagyarmat, $\mathrm{SE}=$ Sellye, $\mathrm{BU}=$ Bujak, $\mathrm{KA}=\mathrm{Karapancsa}, \mathrm{UZ}=\mathrm{Uzsa}, \mathrm{SU}=\mathrm{Süttö}, \mathrm{EI}^{*}=$ Eisenstadt, $\mathrm{ACH}=$ Achenkirch, $\mathrm{VN}=$ Vosges du Nord, DON $=$ Donon, $\mathrm{JPV}^{*}=$ St Augustin Reserve (animals originating from $\mathrm{VN}$ ).

dehydrogenase (SDH, EC 1.1.1.14, L), lactate dehydrogenase (LDH, EC 1.1.1.27, $\mathrm{K})$, malate dehydrogenase (MDH, EC 1.1.1.37), malic enzyme (ME, EC 1.1.1.40, K), isocitrate dehydrogenase (IDH, EC 1.1.1.42, K), 6-phosphogluconate dehydrogenase (PGD, EC 1.1.1.44, K), glucose dehydrogenase (GDH, EC 1.1.1.47, L) glucose-6phosphate dehydrogenase (GPD, EC 1.1.1.49, K), xanthine dehydrogenase (XDH, EC 1.2.3.2, L) glutamate dehydrogenase (GLUD, EC 1.4.1.3, L) catalase (CAT, EC 1.11.1.6), superoxide dismutase (SOD, EC 1.15.1.1, K), purine nucleoside phosphorylase (NP, EC 2.4.2.1, K), aspartate aminotransferase (AAT, EC 2.6.1.1, $\mathrm{K})$, hexokinase (HK, EC 2.7.1.1, K, H), pyruvate kinase (PK, EC 2.7.1.40, H) creatine kinase (CK, EC 2.7.3.2, K, H), adenylate kinase (AK, EC 2.7.4.3, K, H), phosphoglucomutase (PGM, EC 2.7.5.1, K), esterases (ES, EC 3.1.1.1, K), acid phosphatase (ACP, EC 3.1.3.2, K), fructose-1,6-diphosphatase (FDP, EC 3.1.3.11, $\mathrm{L}$ ), peptidases (PEP, EC 3.4.11, K), aminoacylase-1 (ACY-1, EC 3.5.1.14, K), adenosine deaminase (ADA, EC 3.5.4.4, K), aldolase (ALDO, EC 4.1.2.13, H), fumarate hydratase (FH, EC 4.2.1.2, L), mannose phosphate isomerase (MPI, EC 5.3.1.8, K), glucose phosphate isomerase (GPI, EC 5.3.1.9, K).

The interpretation of electrophoretic band-patterns was carried out following the principles of Harris and Hopkinson (1976) and Harris (1980). Since no family studies could be performed, to reduce the possibility of misinterpretation samples 
containing enzyme variants were prepared once again and submitted to repeated electrophoretic runs. Furthermore, the results were compared to genetic variation in deer as described by other authors (see table IV for references) and to that detected in deer and other mammals in our laboratory, where the same enzyme systems were investigated (eg Hartl, 1986b, 1987; Miller and Hartl, 1986, 1987; Hartl and Csaikl, 1987; Hartl and Reimoser, 1988; Hartl et al, 1988a; Leitner and Hartl, 1988; Hartl et al, 1990a). The number of genetic loci determining the various isoenzyme systems was assessed by comparison with data on deer species found in the literature (Table IV) and results from studies on the biochemical systematics of Artiodactyla and the homology of isoenzyme loci among mammals (see Hartl et al, $1988 \mathrm{~b}, 1990 \mathrm{~b}, \mathrm{c}$ ). Isoenzymes (and the corresponding gene loci) were assigned with numbers from the most cathodally to the most anodally migrating fraction. The most common alloenzyme (and the corresponding allele) in population BK* (Fig 1) was designated arbitrarily "100"; variant alloenzymes (alleles) in the same or in other populations were designated according to their relative mobility.

To estimate genetic variation within populations, values of polymorphism $(\bar{P}$, $99 \%$ criterion), expected $(\bar{H})$ and observed $\left(\bar{H}_{o}\right)$ average heterozygosity were calculated according to Ayala (1977). We also calculated the average gene diversity within subpopulations $\left(H_{S}\right)$, the total gene diversity $\left(H_{T}\right)$, the average gene diversity among subpopulations $\left(D_{S T}\right)$ and the relative magnitude of gene diversity among subpopulations $\left(G_{S T}\right)$ according to Nei (1975). To examine the absolute genetic divergence among populations, several distance measures as compiled by Rogers (1986) were applied. Since the results obtained by using these different distance measures were very similar (as to be expected for small distances at the population level), only Nei's (1972) standard genetic distance and its version including a correction for small sample sizes (Nei, 1978) are presented in this paper.

To examine biochemical genetic relationships among the red deer samples studied, dendrograms were constructed by various methods (rooted and unrooted Fitch-Margoliash tree, Cavalli-Sforza-Edwards tree, Wagner network, UPGMA; see Hartl et al, 1990b) using the PHYLIP-programme package of Felsenstein (see Felsenstein, 1985). Since in some of the dendrograms only distances can be used which fulfill the triangle inequality, Rogers distances were chosen in these cases.

To test the influence of sample size and the composition of genetic loci chosen, the bootstrap and the jackknife methods were applied (for the use of the bootstrap in phylogeny, see Felsenstein, 1985). For the bootstrap, all observed allele frequencies are used to simulate new frequencies according to the sample sizes of the various demes studied. For the jackknife, $25 \%$ of the gene loci are randomly omitted. In each method, 100 new data sets are generated and used to construct phenograms, which form the basis for a consensus tree. The latter displays the most stable clusters and in a comparison with the original tree the weak points in the data become visible.

\section{RESULTS}

In the French animals a total of 29 isoenzyme systems representing 47 presumptive structural loci was investigated. Because of the absence of heart samples only 23 isoenzyme systems could be screened in the Hungarian animals. The latter set of enzymes is identical with that investigated by Hartl (1986a) in Austrian red deer 
and represents 38 putative loci. The following loci were found to be polymorphic: $L d h-2, M e-1, I d h-2$, Sod-2, Pgm-2, Acp-1, Acp-2, Mpi and Gpi-1. In all cases, the heterozygote band-patterns were consistent with the known quaternary structure of the enzymes concerned. The isoenzymes ME-2, ES-2, ES-3, NP, and ACP-1 in the Austrian animals were not consistently scorable and therefore omitted from the calculations of genetic variability and differentiation, which are based on the 34 genetic loci scored in all the samples. The following loci were monomorphic (those screened only in French red deer are given in parentheses): $S d h, L d h-1$, Mdh-1, Mdh-2, Idh-1, Pgd, Gdh, Gpd, (Xdh), Glud, Cat, Sod-1, Aat-1, Aat-2, (Pk), $H k-1, H k-2,(H k-3),(C k-1), C k-2, A k-1, A k-2, P g m-1, P g m-3, E s-1$, (Es-d), (Fdp), Pep-1, Pep-2, Acy-1, Ada, (Aldo), (Fh), and Gpi-2.

Allele frequencies are given in table $I$, values of polymorphism, heterozygosity and average heterozygosity are shown in table II. Genetic distances, corrected for small sample sizes (Nei, 1978), are listed in table III. The relative amount of genetic differentiation between sampling sites is $10.4 \%\left(H_{S}=0.354, H_{T}=0.0395\right.$, $D_{S T}=0.0041, G_{S T}=0.1038$ ).

When all sampling sites are included, the dendrograms based on various distance measures and constructed by different cluster algorithms show only poor agreement with the geographic distributions of samples (see eg fig 2). It must be considered, however, that nearly half of them are quite small populations living isolated in enclosures, where extensive allele frequency changes, due to the founder effect, inbreeding, genetic drift, hybridisation of red deer from different provenances (see eg Bergmann, 1976; Kleymann, 1976; Leitner and Hartl, 1988; Hartl, 1989) and possibly also selection (Hartl et al, in preparation), are to be expected. Therefore the dendrograms were recalculated for only the free-ranging demes and in this case, except for changes of little significance, the topology among all of them was identical and showed a fairly good agreement with the geographic distribution of sampling sites (examples are shown in Figs 3 and 4). The stability of the main clusters is also demonstrated in a jackknife (Fig 5) and a bootstrap (Fig 6) consensus tree.

\section{DISCUSSION}

The genetic variability detected in the present study with mean $\bar{P}=11.4 \%$ ( $S D$ $2.05 \%$ ) and mean $\bar{H}=3.5 \%$ (SD $0.8 \%$ ) is similar to that obtained in previous investigations in populations of Scotland and Northern Europe (Gyllensten et al, 1983; see table IV). Since the sample of biochemical markers studied by these authors is quite similar to ours, regarding both the number and the composition of enzyme systems, the $\bar{P}$ - and $\bar{H}$-values obtained in both investigations are thoroughly comparable. Our data are less comparable to those of Herzog (1988b) for 2 reasons. One is the very different number of genetic loci studied. The second is that his data are not based on a random sample of proteins, because the set of enzymes examined by Herzog (1988a), where no polymorphism was detected in pure red deer, was simply extended by including proteins, which were already known to be polymorphic in German red deer (Bergmann, 1976; Gyllensten et al, 1983). Therefore, as the author states himself, his data may give an overestimation of overall genetic variability (mean $\bar{P}=13 \%$, mean $\bar{H}=3.4 \%$ ). The problem of the influence of the number and composition of proteins studied can be demonstrated 
Table I. Allele frequencies at the polymorphic loci in red deer from Hungary, Austria and France ( $99 \%$ criterion). $n=$ sample size.

\begin{tabular}{|c|c|c|c|c|c|c|c|c|c|c|}
\hline $\begin{array}{l}\text { Enzyme } \\
\text { locus }\end{array}$ & Allele & $\begin{array}{l}B K^{*} \\
\mathrm{n}=5\end{array}$ & $\begin{array}{l}M Z-1^{*} \\
8\end{array}$ & $\begin{array}{l}M Z-2^{*} \\
13\end{array}$ & $\begin{array}{l}M Z-3^{*} \\
17\end{array}$ & $\begin{array}{l}Z A \\
7\end{array}$ & $\begin{array}{l}G Y^{*} \\
\gamma\end{array}$ & $\begin{array}{l}B A \\
19\end{array}$ & $\begin{array}{l}S E \\
19\end{array}$ & $\begin{array}{l}B U \\
19\end{array}$ \\
\hline \multirow[t]{2}{*}{$L d h-2$} & 100 & 0.900 & 0.937 & 1 & 1 & 1 & 0.929 & 1 & 0.895 & 1 \\
\hline & 84 & 0.100 & 0.063 & 0 & 0 & 0 & 0.071 & 0 & 0.105 & 0 \\
\hline \multirow{2}{*}{$M e-1$} & 100 & 0.900 & 0.750 & 0.667 & 0.882 & 0.571 & 0.929 & 0.921 & 0.868 & 0.947 \\
\hline & 125 & 0.100 & 0.250 & 0.333 & 0.118 & 0.429 & 0.071 & 0.079 & 0.132 & 0.053 \\
\hline \multirow[t]{3}{*}{$I d h-2$} & 100 & 0.700 & 0.562 & 0.731 & 0.618 & 0.571 & 0.571 & 0.737 & 0.605 & 0.500 \\
\hline & 112 & 0 & 0 & 0 & 0 & 0 & 0 & 0 & 0 & 0 \\
\hline & 125 & 0.300 & 0.438 & 0.269 & 0.382 & 0.429 & 0.429 & 0.263 & 0.395 & 0.500 \\
\hline \multirow[t]{2}{*}{ Sod-2 } & -100 & 1 & 1 & 1 & 1 & 1 & 1 & 1 & 1 & 1 \\
\hline & -200 & 0 & 0 & 0 & 0 & 0 & 0 & 0 & 0 & 0 \\
\hline \multirow[t]{3}{*}{ Pgm-2 } & 100 & 1 & 1 & 1 & 1 & 1 & 1 & 1 & 1 & 1 \\
\hline & 89 & 0 & 0 & 0 & 0 & 0 & 0 & 0 & 0 & 0 \\
\hline & 79 & 0 & 0 & 0 & 0 & 0 & 0 & 0 & 0 & 0 \\
\hline \multirow[t]{2}{*}{$A c p-1$} & 100 & 0.600 & 0.417 & 0.625 & 0.769 & 1 & 0.571 & 0.526 & 0.526 & 0.605 \\
\hline & 300 & 0.400 & 0.583 & 0.375 & 0.231 & 0 & 0.429 & 0.474 & 0.474 & 0.395 \\
\hline \multirow[t]{2}{*}{ Acp-2 } & 100 & 0.600 & 0.375 & 0.385 & 0.441 & 0.429 & 0.071 & 0.210 & 0.250 & 0.184 \\
\hline & 85 & 0.400 & 0.625 & 0.615 & 0.559 & 0.571 & 0.929 & 0.790 & 0.750 & 0.816 \\
\hline \multirow[t]{2}{*}{$M p i$} & 100 & 1 & 1 & 1 & 1 & 1 & 1 & 1 & 1 & 1 \\
\hline & 132 & 0 & 0 & 0 & 0 & 0 & 0 & 0 & 0 & 0 \\
\hline \multirow[t]{2}{*}{ Gpi-1 } & -100 & 1 & 0.750 & 1 & 0.971 & 1 & 1 & 1 & 0.895 & 1 \\
\hline & 60 & 0 & 0.250 & 0 & 0.029 & 0 & 0 & 0 & 0.105 & 0 \\
\hline
\end{tabular}

also by our data. If in the French red deer the polymorphism in ACP-1 is included in the calculation of genetic variation, the $\bar{P}$ - and $\bar{H}$-values rise to mean $\bar{P}=13.3 \%$ instead of $11 \%$ and mean $\bar{H}=3.9 \%$ instead of $2.9 \%$, but this is fully compensated by the 8 monomorphic loci investigated additionally in these populations (mean $\bar{P}=10.6 \%$, mean $\bar{H}=3.1 \%$ ). As stated by Gorman and Renzi (1979), slight differences in $\bar{P}_{-}$and $\bar{H}$-values should therefore not be overemphasized. Bearing this argument in mind, a comparison of genetic variability within populations of the more extensively studied deer species (table IV) shows that mean $\bar{P}$ - and $\bar{H}$ values as well as $\bar{P} t$ calculated for the species (by summing up all polymorphic loci in the various demes) are rather high in the white-tailed deer, the reindeer and the roe deer, followed by the red deer. In contrast, the fallow deer and the moose 
Table I (continued).

\begin{tabular}{|c|c|c|c|c|c|c|c|c|c|}
\hline $\begin{array}{l}K A \\
20\end{array}$ & $\begin{array}{l}U Z \\
20\end{array}$ & $\begin{array}{l}S \ddot{U} \\
18\end{array}$ & $\begin{array}{l}E I^{*} \\
21^{\prime}\end{array}$ & $\begin{array}{l}A C H \\
18\end{array}$ & $\begin{array}{l}V N \\
83\end{array}$ & $\begin{array}{l}D O N \\
54\end{array}$ & $\begin{array}{l}J P V^{*} \\
17\end{array}$ & Mean & $S D$ \\
\hline 0.950 & 1 & 0.944 & 1 & 1 & 1 & 1 & 1 & 0.974 & 0.039 \\
\hline 0.050 & 0 & 0.056 & 0 & 0 & 0 & 0 & 0 & 0.026 & \\
\hline 0.950 & 0.800 & 0.944 & 0.833 & 0.912 & 1 & 1 & 1 & 0.875 & 0.119 \\
\hline 0.050 & 0.200 & 0.056 & 0.167 & 0.088 & 0 & 0 & 0 & 0.125 & \\
\hline 0.625 & 0.650 & 0.750 & 0.620 & 0.583 & 0.404 & 0.611 & 0.235 & 0.593 & 0.127 \\
\hline 0 & 0 & 0 & 0 & 0 & 0.036 & 0 & 0 & 0.002 & 0.009 \\
\hline 0.375 & 0.350 & 0.250 & 0.380 & 0.417 & 0.560 & 0.389 & 0.765 & 0.405 & 0.124 \\
\hline 1 & 1 & 1 & 1 & 1 & 0.988 & 0.982 & 0.941 & 0.995 & 0.015 \\
\hline 0 & 0 & 0 & 0 & 0 & 0.012 & 0.018 & 0.059 & 0.005 & \\
\hline 1 & 1 & 1 & 0.929 & 1 & 0.982 & 0.954 & 1 & 0.992 & 0.020 \\
\hline 0 & 0 & 0 & 0.071 & 0 & 0.018 & 0.018 & 0 & 0.006 & 0.018 \\
\hline 0 & 0 & 0 & 0 & 0 & 0 & 0.028 & 0 & 0.002 & 0.007 \\
\hline 0.425 & 0.475 & 0.321 & $\mathrm{X}$ & $\mathrm{X}$ & 0.683 & 0.778 & 0.792 & 0.608 & 0.167 \\
\hline 0.575 & 0.525 & 0.679 & $X$ & $\mathrm{X}$ & 0.317 & 0.222 & 0.208 & 0.392 & \\
\hline 0.300 & 0.275 & 0.194 & 0.286 & 0.441 & 0.487 & 0.670 & 0.750 & 0.373 & 0.182 \\
\hline 0.700 & 0.725 & 0.806 & 0.714 & 0.559 & 0.513 & 0.330 & 0.250 & 0.627 & \\
\hline 1 & 1 & 1 & 1 & 0.862 & 1 & 1 & 1 & 0.992 & 0.034 \\
\hline 0 & 0 & 0 & 0 & 0.138 & 0 & 0 & 0 & 0.008 & \\
\hline 0.725 & 0.975 & 1 & 1 & 1 & 1 & 1 & 1 & 0.960 & 0.088 \\
\hline 0.275 & 0.025 & 0 & 0 & 0 & 0 & 0 & 0 & 0.040 & \\
\hline
\end{tabular}

exhibit considerably lower mean values of polymorphism and heterozygosity; in the fallow deer likely (Pemberton and Smith, 1985; Hartl et al, 1986; Randi and Apollonio, 1988), in the moose possibly due to past genetic bottlenecks (Ryman et $a l, 1977,1980)$. The polymorphism at the $I d h-2$ locus has been found (with the exception of Herzog, 1988a,b) in almost all red deer populations studied so far - across several subspecies ( $C$ e elaphus, scoticus, germanicus, hippelaphus and canadensis) - with high frequencies of (most likely) the same variant allele, Idh-2 $2^{125}$ (Dratch, 1983; Gyllensten et al, 1983; Dratch and Gyllensten, 1985; Hartl, 1986). The ubiquitous distribution of this polymorphism can be possibly explained by natural selection, when the results of Pemberton et al (1988), obtained in a red deer population on the Scottish island of Rhum, are considered. These authors detected significant associations between genotypes at the loci $I d h-2, M p i$, and $T f$ 
Table II. Genetic variability in red deer. $H_{0}(H)=$ observed (expected) heterozygosity, loci. $\bar{H}_{o} \bar{H}$ and $\bar{P}$ are calculated over 34 genetic loci (Acp-1 omitted).

\begin{tabular}{|c|c|c|c|c|c|c|c|c|c|c|}
\hline $\begin{array}{l}\text { Enzyme } \\
\text { locus }\end{array}$ & & $B K^{*}$ & $M Z-1^{*}$ & $M Z-2^{*}$ & $M Z-3^{*}$ & $Z A$ & $G Y^{*}$ & $B A$ & $S E$ & $B U$ \\
\hline \multirow[t]{2}{*}{$L d h-2$} & $H_{0}$ & 0.200 & 0.125 & 0 & 0 & 0 & 0.143 & 0 & 0.158 & 0 \\
\hline & $H$ & 0.180 & 0.118 & 0 & 0 & 0 & 0.132 & 0 & 0.188 & 0 \\
\hline \multirow[t]{2}{*}{$M e-1$} & $H_{o}$ & 0.200 & 0.500 & 0.333 & 0.235 & 0.571 & 0.143 & 0.158 & 0.263 & 0.105 \\
\hline & $H$ & 0.180 & 0.375 & 0.444 & 0.208 & 0.490 & 0.132 & 0.145 & 0.229 & 0.100 \\
\hline \multirow[t]{2}{*}{ Idh-2 } & $H_{o}$ & 0.600 & 0.625 & 0.385 & 0.294 & 0.571 & 0.857 & 0.526 & 0.579 & 0.684 \\
\hline & $H$ & 0.420 & 0.492 & 0.393 & 0.472 & 0.490 & 0.490 & 0.388 & 0.478 & 0.500 \\
\hline \multirow[t]{2}{*}{ Sod-2 } & $H_{o}$ & 0 & 0 & 0 & 0 & 0 & 0 & 0 & 0 & 0 \\
\hline & $H$ & 0 & 0 & 0 & 0 & 0 & 0 & 0 & 0 & 0 \\
\hline \multirow[t]{2}{*}{ Pgm-2 } & $H_{o}$ & 0 & 0 & 0 & 0 & 0 & 0 & 0 & 0 & 0 \\
\hline & $H$ & 0 & 0 & 0 & 0 & 0 & 0 & 0 & 0 & 0 \\
\hline \multirow[t]{2}{*}{$A c p-1$} & $H_{o}$ & 0.400 & 0.833 & 0.417 & 0.461 & 0 & 0.490 & 0.421 & 0.526 & 0.368 \\
\hline & $H$ & 0.480 & 0.486 & 0.469 & 0.355 & 0 & 0.571 & 0.499 & 0.499 & 0.478 \\
\hline \multirow[t]{2}{*}{$A c p-2$} & $H_{o}$ & 0.800 & 0.500 & 0.308 & 0.412 & 0.571 & 0.143 & 0.316 & 0.500 & 0.368 \\
\hline & $H$ & 0.480 & 0.469 & 0.474 & 0.493 & 0.490 & 0.132 & 0.332 & 0.375 & 0.300 \\
\hline \multirow[t]{2}{*}{$M p i$} & $H_{o}$ & 0 & 0 & 0 & 0 & 0 & 0 & 0 & 0 & 0 \\
\hline & $H$ & 0 & 0 & 0 & 0 & 0 & 0 & 0 & 0 & 0 \\
\hline \multirow[t]{5}{*}{$G p i-1$} & $H_{o}$ & 0 & 0.250 & 0 & 0.059 & 0 & 0 & 0 & 0.210 & 0 \\
\hline & $H$ & 0 & 0.375 & 0 & 0.056 & 0 & 0 & 0 & 0.188 & 0 \\
\hline & $\bar{H}_{o}$ & 0.053 & 0.059 & 0.030 & 0.029 & 0.050 & 0.038 & 0.029 & 0.050 & 0.034 \\
\hline & $\overline{\bar{H}}$ & 0.037 & 0.054 & 0.039 & 0.036 & 0.043 & 0.026 & 0.025 & 0.043 & 0.026 \\
\hline & $\bar{P}$ & 0.118 & 0.147 & 0.088 & 0.118 & 0.088 & 0.118 & 0.088 & 0.147 & 0.088 \\
\hline
\end{tabular}

(the variation at each of them is represented by 2 alleles) and juvenile survival. In $I d h$ - 2 , heterozygote female calves survive much better than homozygotes, whereas male homozygotes survive better than heterozygotes, and the difference in survival is smaller. It cannot be decided if selection acts on the enzyme locus itself or at a closely linked gene or gene complex (Pemberton et al, 1988). At the Mpi locus, selection against the rare allele, being positively associated with juvenile mortality, may also be responsible for the pattern of variation observed at this locus in Cervus 
$\bar{H}_{o}(\bar{H})=$ observed (expected) average heterozygosity, $\bar{P}=$ proportion of polymorphic

\begin{tabular}{llllllll}
\hline$K A$ & $U Z$ & $S \ddot{U}$ & $E I^{*}$ & $A C H$ & $V N$ & $D O N$ & $J P V^{*}$ \\
& & & & & & & \\
\hline 0.100 & 0 & 0.111 & 0 & 0 & 0 & 0 & 0 \\
0.095 & 0 & 0.106 & 0 & 0 & 0 & 0 & 0 \\
& & & & & & & \\
0.100 & 0.300 & 0.111 & 0.238 & 0.176 & 0 & 0 & 0 \\
0.095 & 0.320 & 0.106 & 0.278 & 0.161 & 0 & 0 & 0 \\
& & & & & & & \\
0.650 & 0.500 & 0.278 & 0.380 & 0.500 & 0.434 & 0.592 & 0.353 \\
0.469 & 0.455 & 0.375 & 0.471 & 0.486 & 0.522 & 0.475 & 0.360 \\
& & & & & & & \\
0 & 0 & 0 & 0 & 0 & 0.024 & 0.037 & 0.117 \\
0 & 0 & 0 & 0 & 0 & 0.024 & 0.035 & 0.111 \\
& & & & & & & \\
0 & 0 & 0 & 0.142 & 0 & 0.036 & 0.093 & 0 \\
0 & 0 & 0 & 0.132 & 0 & 0.035 & 0.089 & 0 \\
0.550 & 0.750 & 0.500 & $\mathrm{X}$ & $\mathrm{X}$ & 0.465 & 0.400 & 0.417 \\
0.489 & 0.489 & 0.436 & $\mathrm{X}$ & $\mathrm{X}$ & 0.433 & 0.345 & 0.330 \\
& & & & & & & \\
0.400 & 0.450 & 0.278 & 0.380 & 0.529 & 0.425 & 0.434 & 0.375 \\
0.420 & 0.399 & 0.313 & 0.408 & 0.493 & 0.500 & 0.442 & 0.375 \\
& & & & & & & \\
0.420 & 0.048 & 0 & 0 & 0 & 0 & 0 & 0 \\
\hline 0.050 & 0.038 & 0.023 & 0.034 & 0.044 & 0.027 & 0.034 & 0.025 \\
0.147 & 0.118 & 0.118 & 0.118 & 0.118 & 0.118 & 0.118 & 0.088
\end{tabular}

elaphus. In spite of the lack of some rare alleles, genetic variability within enclosures is not lower than in free-ranging demes. However, allele frequencies at the highly polymorphic loci may have been altered by various influences leading to unexpected positions of the corresponding provenances in a dendrogram (Fig 2). In contrast, the dendrograms of only free-ranging demes are in quite good agreement with their geographic distribution (Figs 3, 4).

Although absolute genetic differentiation is very small (mean $\mathrm{D}(\mathrm{Nei}, 1978)=$ $0.0030, S D=0.0037$; mean D $(\mathrm{Nei}, 1972)=0.0045, S D=0.0036)$ even over large geographic distances, relative genetic differentiation $\left(G_{S T}=10.4 \%\right)$ is higher 
Table III. Genetic identities - above diagonal - and genetic distances - below diagonal -

\begin{tabular}{|c|c|c|c|c|c|c|c|c|}
\hline & $B K^{*}$ & $M Z-1^{*}$ & $M Z-2^{*}$ & $M Z-3^{*}$ & $Z A$ & $G Y^{*}$ & $B A$ & $S E$ \\
\hline $\mathrm{K}^{*}$ & - & 0.9993 & 0.9995 & 1.0014 & 0.9988 & 0.9941 & 0.9988 & (000 \\
\hline $1 \mathrm{Z}-1^{*}$ & 0.0007 & - & 0.9996 & 1.0001 & 1.0005 & 0.9973 & 0.9996 & 0.9989 \\
\hline $\mathrm{MZ}-2^{*}$ & 0.0005 & 0.0004 & - & 0.9994 & .0014 & 0.9958 & 0.9996 & 0.9982 \\
\hline MZ-3* & -0.0014 & -0.0001 & 0.0006 & - & 0.9993 & 0.9971 & 1.0001 & 1.0005 \\
\hline $\mathrm{A}$ & & 0.0005 & -0.00 & 0.00 & - & & & 0.9982 \\
\hline $\mathrm{GY}^{*}$ & .0059 & 0.0027 & 0.0042 & 0.00 & 0.0052 & - & 0.9995 & 0.9967 \\
\hline $3 \mathrm{~A}$ & 0012 & 04 & 0.0004 & -0.00 & & & - & 0.9994 \\
\hline $\mathrm{E}$ & -0.00 & 1 & 0.00 & -0.0 & & & & - \\
\hline $\mathrm{BU}$ & 025 & .0024 & 0.0 & 0.0 & 39 & 02 & 001 & 0.0019 \\
\hline $\mathrm{KA}$ & & -0.00 & & 0.0 & 0.0021 & -0.0002 & -0.0 & 0.0012 \\
\hline $\mathrm{UZ}$ & 0.0043 & 0.0021 & & & & -0 . & 004 & 0.0018 \\
\hline SÜ & 0.0027 & -0.0009 & 0.0040 & 0.00 & & 24 & 0.0019 & 0.0025 \\
\hline $\mathrm{EI}^{*}$ & 0.0013 & -0.0001 & -0.0002 & 0.0000 & & 0.0006 & -0.0007 & 0.0009 \\
\hline$\triangle C H$ & & & & & & & & 0.0024 \\
\hline VN & 0.0012 & 0.0029 & 0.0058 & 0.0011 & & 0.0051 & 0.0028 & 0.0010 \\
\hline DON & -0.0012 & 0.0047 & 0.0054 & 0.0014 & 0.0056 & 0.0102 & 0.0048 & 0.0017 \\
\hline $\mathrm{JPV}^{*}$ & 0.0054 & 0.0093 & 0.0139 & 0.0070 & 0.0102 & 0.0165 & 0.0113 & 0.0065 \\
\hline
\end{tabular}

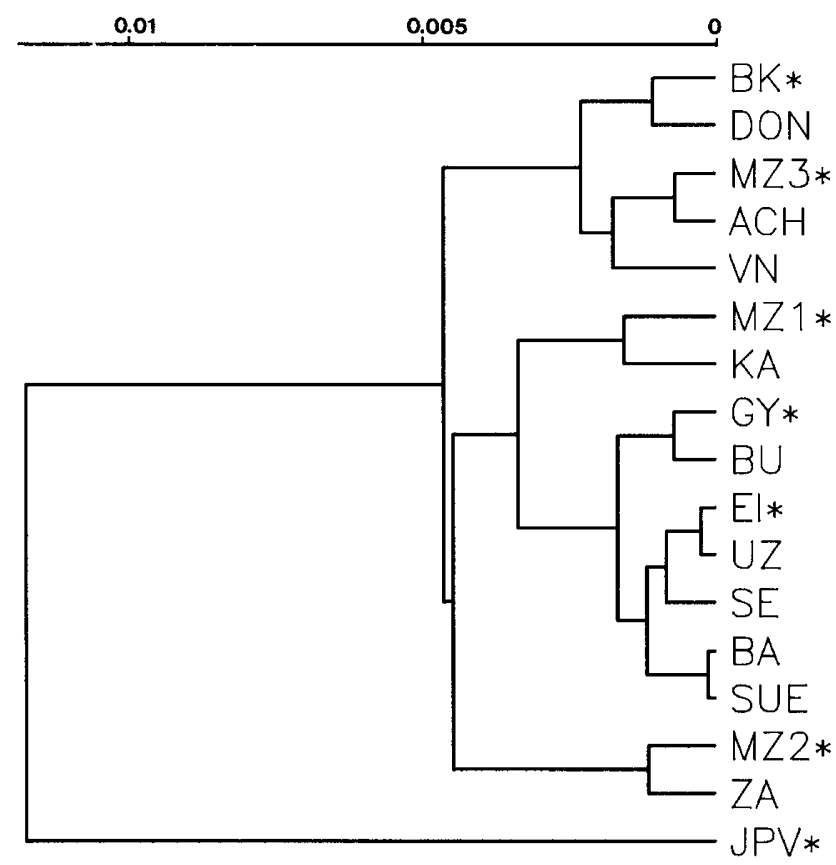

Fig 2. Rooted dendrogram, showing genetic relationships among all red deer populations studied (UPGMA/D: Nei, 1972). 
between red deer populations, calculated according to Nei (1978).

\begin{tabular}{lclllllll}
\hline$B U$ & $K A$ & $U Z$ & $S \ddot{U}$ & $E I^{*}$ & $A C H$ & $V N$ & $D O N$ & $J P V^{*}$ \\
\hline 0.9975 & 0.9983 & 0.9957 & 0.9973 & 0.9987 & 0.9973 & 0.9988 & 1.0012 & 0.9946 \\
0.9976 & 1.0008 & 0.9979 & 1.0009 & 1.0001 & 0.9972 & 0.9971 & 0.9953 & 0.9907 \\
0.9983 & 0.9984 & 0.9960 & 0.9960 & 1.0002 & 0.9977 & 0.9943 & 0.9946 & 0.9862 \\
0.9988 & 0.9995 & 0.9984 & 0.9985 & 1.0000 & 0.9983 & 0.9989 & 0.9986 & 0.9931 \\
0.9961 & 0.9979 & 0.9958 & 0.9949 & 0.9997 & 0.9952 & 0.9954 & 0.9944 & 0.9899 \\
0.9998 & 1.0002 & 1.0007 & 0.9976 & 0.9994 & 1.0000 & 0.9949 & 0.9899 & 0.9837 \\
0.9999 & 1.0002 & 0.9996 & 0.9981 & 1.0007 & 0.9995 & 0.9972 & 0.9952 & 0.9887 \\
0.9981 & 0.9988 & 0.9982 & 0.9975 & 0.9991 & 0.9976 & 0.9990 & 0.9983 & 0.9935 \\
- & 0.9997 & 0.9990 & 0.9979 & 1.0000 & 1.0006 & 0.9949 & 0.9934 & 0.9840 \\
0.0003 & - & 0.9997 & 0.9999 & 1.0003 & 0.9997 & 0.9967 & 0.9941 & 0.9879 \\
0.0010 & 0.0003 & - & 0.9977 & 0.9992 & 0.9988 & 0.9974 & 0.9928 & 0.9888 \\
0.0021 & 0.0000 & 0.0023 & - & 0.9983 & 0.9979 & 0.9959 & 0.9940 & 0.9876 \\
-0.0000 & -0.0003 & 0.0008 & 0.0017 & - & 0.9996 & 0.9963 & 0.9945 & 0.9875 \\
-0.0006 & 0.0003 & 0.0012 & 0.0021 & 0.0004 & - & 0.9944 & 0.9928 & 0.9831 \\
0.0051 & 0.0033 & 0.0026 & 0.0041 & 0.0037 & 0.0056 & - & 0.9981 & 0.9972 \\
0.0067 & 0.0059 & 0.0072 & 0.0060 & 0.0055 & 0.0072 & 0.0019 & - & 0.9960 \\
0.0161 & 0.0121 & 0.0113 & 0.0124 & 0.0126 & 0.0170 & 0.0028 & 0.0040 & - \\
\hline
\end{tabular}

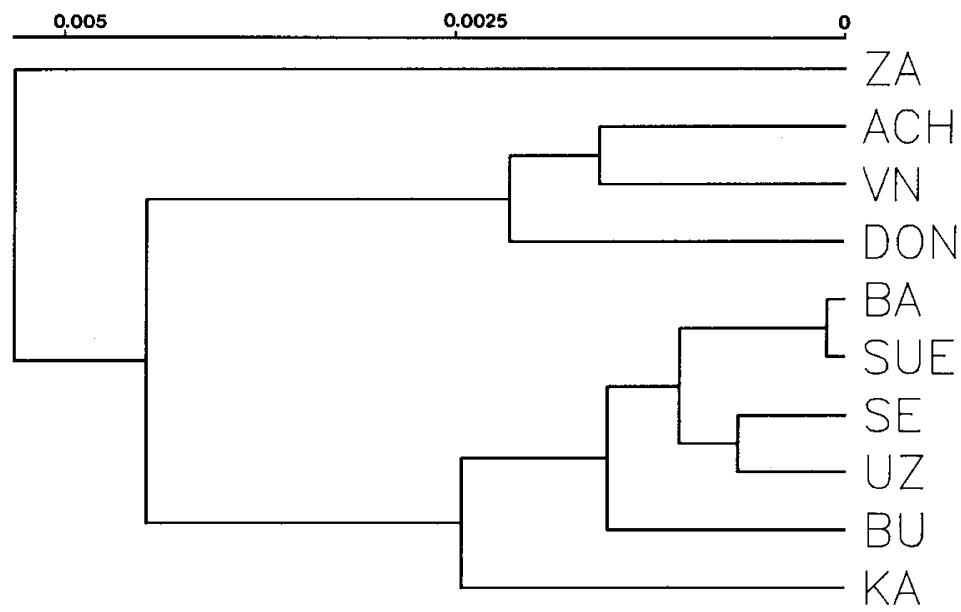

Fig 3. Rooted dendrogram, showing genetic relationships among free-ranging populations of red deer (UPGMA/D: Nei, 1972). When corrected distances (Nei, 1978) are used ZA is more closely related to the Hungarian cluster (BA, SUE, SE, UZ, BU, KA) than the French/Austrian cluster (VN, DON, ACH). 
than that detected by Gyllensten et al (1983); $G_{S T}=5 \%$ ). Nevertheless, since the relative differentiation among subspecies is $\approx 22 \%$ (Gyllensten et al, 1983), together with Nei's D-values our results indicate that there is no major genetic differentiation among the demes investigated in the present study. Furthermore, part of the genetic diversity between populations seems to be due to the inclusion of artificial populations living in enclosures as it is still lower among only freeranging demes $\left(G_{S T}=7.9 \%\right.$; mean D $(\mathrm{Nei}, 1978)=0.0027, S D=0.0022$; mean $\mathrm{D}(\mathrm{Nei}, 1972)=0.0038, S D=0.0022)$.

Based on antler characters, in the Hungarian red deer the existence of different "local races" has been proposed (Szederjei, 1965). After examining various antler traits in the same populations investigated in the present study, this hypothesis was rejected by Köller et al $(1988,1989)$. Our electrophoretic data, showing very low genetic distances among the Hungarian samples, confirm this result. In the French red deer, according to Lang (1987) all animals living in the Vosges originate from a small remaining population in the mountain range of Donon $(\approx 500$ individuals in 1870). From there the Northern Vosges were colonized, which are now isolated from the Donon area by the Paris-Strasbourg motorway (see fig 1). Our results indicate that genetic variation of deer in the Donon area (DON) is not higher than in their descendants in the Northern Vosges (VN). However, according to the distribution of some rare alleles $\left(I d h-2^{112}, P g m-2^{79}\right)$ and the genetic distances shown in table III, at present the populations DON and VN may be in fact genetically isolated by the motorway mentioned above. In Austria there seems to be a rather continuous gene flow throughout most parts of the country, resulting in the low genetic distance between the populations $\mathrm{ACH}$ and $\mathrm{EI}^{*}$, although the latter has been in an enclosure since 1958 (Hartl, 1986a).

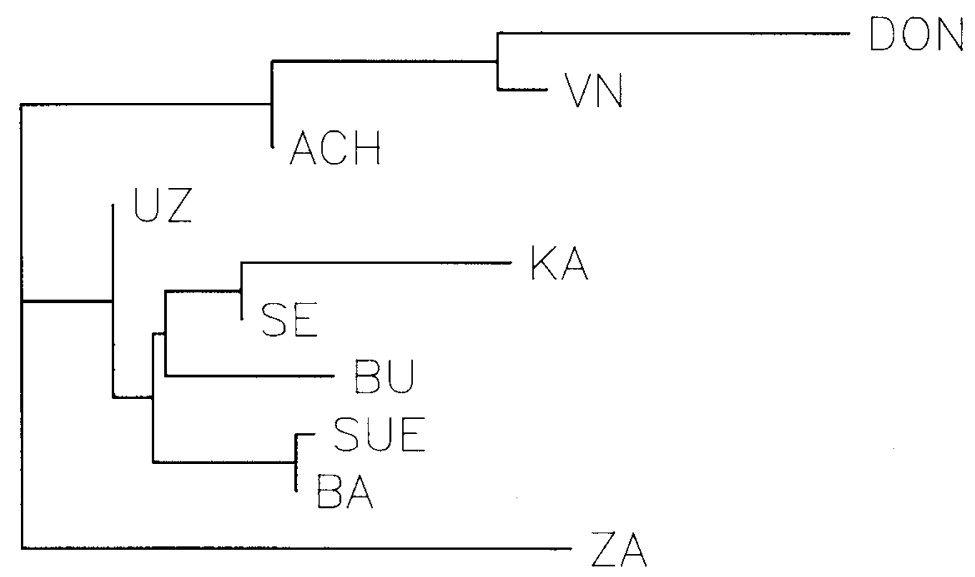

Fig 4. Unrooted dendrogram showing genetic relationships among free ranging populations of red deer (Fitch-Felsenstein, 1985/D: Nei, 1972). 


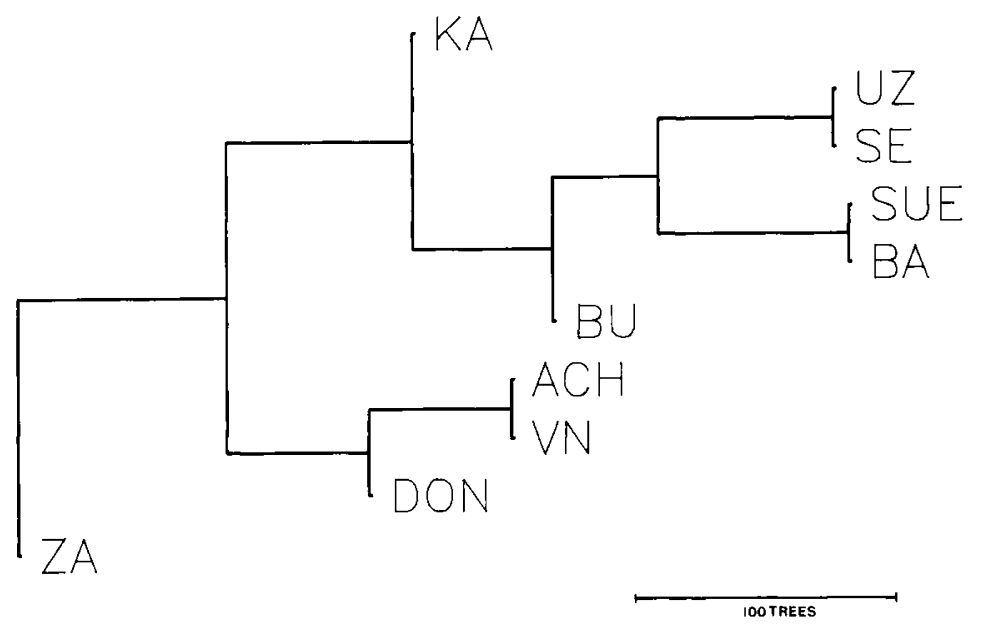

Fig 5. Majority rule jackknife consensus tree, showing the stability of the clusters presented in figure 3 with respect to the influence of gene loci investigated.

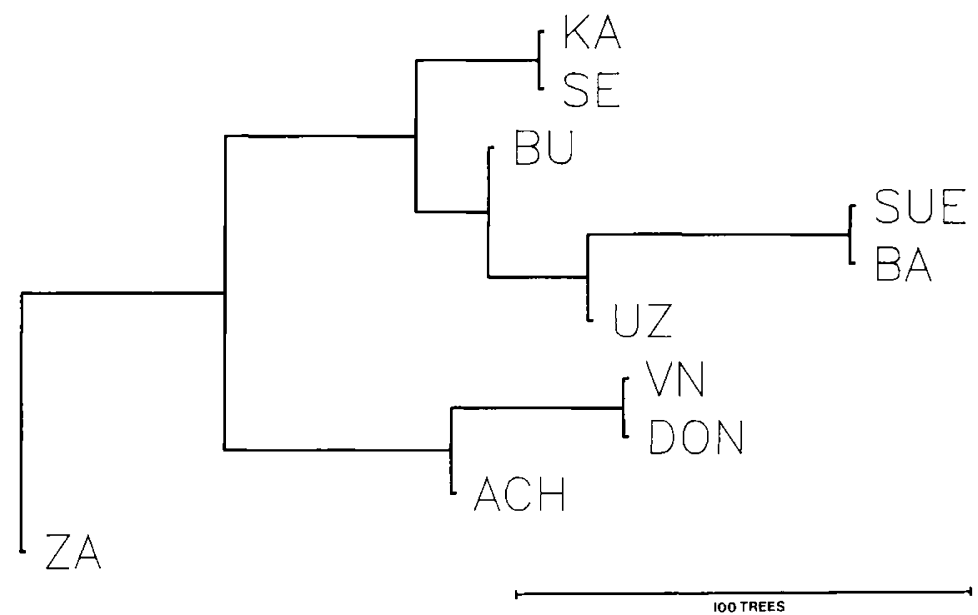

Fig 6. Majority rule bootstrap consensus tree, showing the stability of the clusters presented in figure 3 with respect to sample sizes. 
Table IV. Genetic variation in deer species. $n I=$ sample of individuals, $n P=$ sample of from the data given in the references), $\overparen{P}=$ proportion of polymorphic loci (if more popuare studied the mean $\bar{H}$ is given), $G_{S T}=$ relative magnitude of gene differentiation among tions, ${ }^{*}=$ values for only free-ranging demes in parentheses, ${ }^{* *}=$ transferrin included, Ramsey et al, 1979; Gyllensten et al, 1980), and may lead to an overestimation of Røed, 1985b).

\begin{tabular}{|c|c|c|c|c|c|c|}
\hline Species & $n I$ & $n P$ & $n L$ & $\begin{array}{l}\bar{P}_{t} \\
\text { (percent) }\end{array}$ & $\begin{array}{l}\bar{P} \\
\text { (percent) }\end{array}$ & $\begin{array}{l}\bar{H} \\
\text { (percent) }\end{array}$ \\
\hline Fallow deer & $88-368$ & $9-22$ & 30 & 0.0 & 0.0 & 0.0 \\
\hline \multirow[t]{2}{*}{ (Dama dama) } & $18-118$ & 1 & 15 & 6.6 & 6.6 & 6.6 \\
\hline & 180 & 1 & 51 & 2.0 & 2.0 & 0.6 \\
\hline Red deer & 594 & 22 & 34 & 20.6 & 7.7 & 2.2 \\
\hline \multirow{4}{*}{ (Cervus elaphus) } & 27 & - & 19 & 15.8 & 15.8 & 4.7 \\
\hline & 145 & 6 & 28 & 17.9 & 11.9 & 2.7 \\
\hline & 146 & 4 & 15 & 13.0 & 13.0 & 3.4 \\
\hline & $365(277)$ & $17(10)$ & 34 & $23.5(20.6)$ & $11.4(11.5)$ & $3.5(3.5)$ \\
\hline (Wapiti) & $25-200$ & 1 & 24 & 4.2 & 4.2 & 1.2 \\
\hline (Wapiti) & 49 & - & 19 & 10.5 & 10.5 & 1.5 \\
\hline (Wapiti) & 243 & 11 & 28 & 17.9 & 12.3 & 2.3 \\
\hline Moose & $60-1384$ & 3 & 23 & 4.3 & 4.3 & 0.06 \\
\hline \multirow[t]{2}{*}{ (Alces alces) } & 734 & 18 & 23 & 21.7 & 9.4 & 2.0 \\
\hline & 165 & - & 19 & 15.8 & 15.8 & 1.7 \\
\hline Reindeer & 20 & - & 19 & 5.3 & 5.3 & 1.4 \\
\hline \multirow[t]{3}{*}{ (Rangifer tarandus) } & 198 & 4 & 34 & 23.5 & 13.2 & 2.2 \\
\hline & 239 & 3 & 35 & 28.6 & 19.0 & 3.9 \\
\hline & - & 5 & 35 & 25.7 & 16.0 & 4.9 \\
\hline White-tailed deer & 753 & 8 & 20 & - & 35.8 & 7.4 \\
\hline \multirow[t]{2}{*}{ (Odocoileus virginianus) } & 326 & 4 & 57 & 31.6 & 16.1 & 6.2 \\
\hline & 1549 & - & 19 & - & 36.8 & 7.8 \\
\hline $\begin{array}{l}\text { Red brocket } \\
\text { (Mazama americana) }\end{array}$ & 52 & - & 19 & 57.9 & 57.9 & 7.0 \\
\hline Roe deer & 24 & - & 19 & 10.5 & 10.5 & 2.4 \\
\hline (Capreolus capreolus) & 161 & 5 & 41 & 21.9 & 17.6 & 5.4 \\
\hline
\end{tabular}

\section{ACKNOWLEDGMENTS}

The authors wish to thank the local hunters in Hungary and France for the collection of samples and the hunters in the Alsace for financial support. The excellent technical assistance of A Haiden and the graphic help of Ing J Zandl are gratefully acknowledged. 
populations, $n L=$ sample of loci, $\bar{P} t=$ total proportion of polymorphic loci (calculated lations are studied the mean $\bar{P}$ is given), $\bar{H}=$ average heterozygosity (if more populations populations, $D=$ mean standard genetic distance (Nei, 1972 or 1978) among populawhich is highly polymorphic in red deer, moose, reindeer and white-tailed deer (see also average heterozygosity in comparison to data based only on isoenzymes (Sarich, 1977;

\begin{tabular}{|c|c|c|}
\hline$G_{S T}$ & $D$ & $\operatorname{Ref}$ \\
\hline 0.0 & 0.0 & Pemberton and Smith $(1985)^{* *}$ \\
\hline- & - & Hartl et al $(1986)^{* *}$ \\
\hline- & - & Randi and Apollonio $(1988)^{* *}$ \\
\hline 4.9 & $0.001-0.004$ & Gyllensten et al (1983) \\
\hline- & - & Baccus et al (1983) \\
\hline- & - & Dratch and Gyllensten (1985) \\
\hline $1.0\left(\mathrm{~F}_{S T}\right)$ & $0-0.008$ & Herzog $(1988 b)^{* *}$ \\
\hline $10.4(7.9)$ & $0.003(0.003)$ & This study* \\
\hline- & - & Cameron and Vyse (1978) \\
\hline- & - & Baccus et al (1983) \\
\hline- & - & Dratch and Gyllensten (1985) \\
\hline- & - & Ryman et al (1977) \\
\hline 9.4 & 0.002 & Ryman et al (1980) \\
\hline- & - & Baccus et al (1983) \\
\hline- & - & Baccus et al (1983) \\
\hline $2.9\left(\mathrm{~F}_{S T}\right)$ & $0-0.003$ & Røed (1985a) \\
\hline- & - & $\mathrm{Røed}(1985 \mathrm{~b})^{* *}$ \\
\hline- & $0.001-0.002$ & Røed $(1986)^{* *}$ \\
\hline- & - & Baccus et al (1983) \\
\hline- & - & Sheffield et al (1985) \\
\hline- & - & Smith et al (1986) \\
\hline- & - & Smith et al (1986) \\
\hline- & - & Baccus et al (1983) \\
\hline 8.5 & 0.007 & Hartl and Reimoser (1988) \\
\hline
\end{tabular}

\section{REFERENCES}

Albert S (1984) Untersuchung der Hämoglobin-Varianten von Rotwild Cervus elaphus mit Hilfe der Elektrofokussierung. Inaugural Dissertation, Justus-Liebig Universität, Giessen, pp 127

Ayala FJ (1977) The genetic structure of populations. In: Evolution (Dobzhansky T, Ayala F, Stebbins GL, Valentine JW, eds) WH Freeman \& Co, San Francisco, $20-56$ 
Baccus R, Ryman N, Smith MH, Reuterwall C, Cameron D (1983) Genetic variability and differentiation of large grazing mammals. J Mammal 64, 109-120

Bergmann F (1976) Beiträge zur Kenntnis der Infrastrukturen beim Rotwild. II. Erste Versuche zur Klärung der genetischen Struktur von Rotwildpopulationen an Hand von Serumprotein-Polymorphismen. $Z$ Jagdwiss 22, 28-35

Bergmann F, Moser K (1985) Protein-Polymorphismen in Rotwildpopulationen der Bundesrepublik Deutschland. In: Tagungsbericht. I. Symposium über Wildtiergenetik Giessen-Rauischholzhausen, 24-27th October 1985, 147-157

Cameron DG, Vyse ER (1978) Heterozygosity in Yellowstone Park elk, Cervus canadensis. Biochem Genet 16, 651-657

Dratch P (1983) Enzyme variation in Scottish red deer, Cervus elaphus: population subdivision and its management implications. Proc XV Congr Int Fauna Cinegetica y Silvestre, Trujillo, 1981, 279-280

Dratch P, Gyllensten U (1985) Genetic differentiation of red deer and North American elk (Wapiti). Biology of deer production. $R$ Soc $N Z$ Bull 22, 37-40

Felsenstein J (1985) Confidence limits on phylogenies: an approach using the bootstrap. Evolution 39, 783-791

Gorman GC, Renzi J Jr (1979) Genetic distance and heterozygosity estimates in electrophoretic studies: effects of sample size. Copeia 2, 242-249

Gyllensten U, Reuterwall C, Ryman N, Stahl G (1980) Geographical variation of transferrin allele frequencies in three deer species from Scandinavia. Hereditas 92, 237-241

Gyllensten U, Ryman N, Reuterwall C, Dratch P (1983) Genetic differentiation in four European subspecies of red deer (Cervus elaphus L). Heredity 51, 561-580

Harris H, Hopkinson DA (1976) Handbook of Enzyme Electrophoresis in Human Genetics. North Holland, Amsterdam

Harris H (1980) The Principles of Human Biochemical Genetics. North Holland, Amsterdam, pp 554

Hartl GB (1986a) Genetische Variabilität beim Rotwild - Auswirkungen anthropogener Einflüsse auf den Genpool von Wildtierpopulationen. In: Proc CIC Meeting on Red Deer, Graz, June 19-22, 1986 (Linn S, ed), GWI Druck GmbH, Munich, 423-431

Hartl GB (1986b) Steinbock und Gemse im Alpenraum - genetische Variabilität und biochemische Differenzierung zwischen den Arten. $Z$ Zool Syst Evolutionsforsch 24, 315-320

Hartl GB, Höger H (1986) Biochemical variation in purebred and crossbred strains of domestic rabbits (Oryctolagus cuniculus L). Genet Res (Camb) 48, 27-34

Hartl GB, Schleger A, Slowak M (1986) Genetic variability in fallow deer, Dama dama L. Anim Genet 17, 335-341

Hartl GB (1987) Biochemical differentiation between the wild rabbit (Oryctolagus cuniculus $\mathrm{L}$ ), the domestic rabbit and the brown hare (Lepus europaeus Pallas). Z Zool Syst Evolutionsforsch 25, 309-316

Hartl GB, Csaikl F (1987) Genetic variability and differentiation in wild boars (Sus scrofa ferus L): comparison of isolated populations. J Mammal 68, 119-125

Hartl GB, Reimoser F (1988) Biochemical variation in roe deer (Capreolus capreolus $\mathrm{L})$ : Are r-strategists among deer genetically less variable than K-strategists? Heredity $60,221-227$ 
Hartl GB, Willing R, Grillitsch M, Klansek E (1988a) Biochemical variation in Mustelidae: are carnivores genetically less variable than other mammals? Zool Anz 221, 81-90

Hartl GB, Göltenboth R, Grillitsch M, Willing R (1988b) On the biochemical systematics of the Bovini. Biochem Syst Ecol 16, 575-579

Hartl GB (1989) Die genetische Variabilität von Wildsäugern und die Folgen der Isolation. In: Die Illusion der Arche Noah - Gefahren für die Arterhaltung durch Gefangenschaftszucht (Schneider E, Oelke H, Gross H eds) Echo-Verlag, Göttingen, 127-138

Hartl GB, Markowski J, Kovacs G, Grillitsch M, Willing R (1990a) Biochemical variation and differentiation in the brown hare (Lepus europaeus) of Central Europe. Z Säugetierk 55, 186-193

Hartl GB, Willing R, Suchentrunk F (1990b) On the biochemical systematics of selected mammalian taxa: empirical comparison of qualitative and quantitative approaches in the evaluation of protein electrophoretic data. Z Zool Syst Evolutionsforsch (in press)

Hartl GB, Burger H, Willing R, Suchentrunk F (1990c) On the biochemical systematics of the Caprini and Rupicaprini. Biochem Syst Ecol 18, 175-182

Herzog A (1986) Biochemisch-genetische Untersuchungen am Rotwild (Cervus elaphus L). In: Proc CIC Meeting on Red Deer, Graz, June 19-22, 1986 (Linn S, ed) GWI Druck GmbH, Munich, 432-434

Herzog S (1988a) Polymorphism and genetic control of erythrocyte 6-phosphogluconate dehydrogenase in the genus Cervus. Anim Genet 19, 291-294

Herzog S (1988b) Cytogenetische und biochemisch-genetische Untersuchungen an Hirschen der Gattung Cervus (Cervidae, Artiodactyla, Mammalia). In: Göttingen Research Notes in Forest Genetics 10, pp 139

Kabai P (1987) Feherjepolimorfizmus vizsgalatok negy hazai szarvasfeleben. Thesis, University of Budapest

Kleymann M (1976) Beiträge zur Kenntnis der Infrastrukturen beim Rotwild. III. Zur genetischen Struktur von Rotwildpopulationen anhand von Blutgruppenvergleichsuntersuchungen. $Z$ Jagdwiss 22, 121-134

Köller J, Kabai P, Demeter A (1988) Untersuchungen zur regionalen Differenzierung ungarischer Rotwildpopulationen anhand morphologischer Geweihmerkmale. $Z$ Jagdwiss 34, 86-97

Köller J, Kabai P, Demeter A (1989) Die Nutzung morphologischer Abwurfstangenmerkmale zur objektiven Differenzierung ungarischer Rotwildpopulationen. Z Jagdwiss 35, 151-163

Lang G (1987) Gestion des populations de Cervidés - Réflexions sur des problèmes de polymorphisme génétique. Thèse de Diplôme d'Etat de docteur en Pharmacie, Université Louis Pasteur, Strasbourg, pp 151

Leitner M, Hartl GB (1988) Genetic variation in the bank vole Clethrionomys glareolus: biochemical differentiation among populations over short geographic distances. Acta Theriol 33, 231-245

Miller C, Hartl GB (1986) Genetic variation in two alpine populations of chamois (Rupicapra rupicapra L). Z Säugetierk 51, 114-121

Miller C, Hartl GB (1987) Genetische Variation bei Gemsen der Alpen (Rupicapra rupicapra L). Z Jagdwiss 33, 220-227 
Nei M (1972) Genetic distance between populations. Am Nat 106, 283-292

Nei M (1975) Molecular Population Genetics and Evolution. North Holland, Amsterdam, pp 288

Nei M (1978) Estimation of average heterozygosity and genetic distance from a small number of individuals. Genetics $89,583-590$

Nevo E, Beiles A, Ben-Shlomo R (1984) The evolutionary significance of genetic diversity: ecological, demographic and life history correlates. In: Evolutionary Dynamics of Genetic Diversity. Lecture Notes in Biomathematics (Mani GS ed), Springer, Berlin, 13-213

Pemberton JM, Smith RH (1985) Lack of biochemical polymorphism in British fallow deer. Heredity 55, 199-207

Pemberton JM, Albon SD, Guinness FE, Clutton-Brock TH (1988) Genetic variation and juvenile survival in red deer. Evolution 42, 921-934

Ramsey PR, Avise JC, Smith MH, Urbston DF (1979) Biochemical variation and genetic heterogeneity in South Carolina deer populations. $J$ Wildl Manage 43, 136-142

Randi E, Apollonio M (1988) Low biochemical variability in European fallow deer (Dama dama L): natural bottlenecks and the effects of domestication. Heredity $61,405-410$

Røed KH (1985a) Genetic variability in Norwegian semi-domestic reindeer (Rangifer tarandus L). Hereditas 102, 177-184

Røed KH (1985b) Comparison of the genetic variation in Svalbard and Norwegian reindeer. Can J Zool 63, 2038-2042.

Røed KH (1986) Genetic variability in Norwegian wild reindeer (Rangifer tarandus L) Hereditas 104, 293-298

Rogers JS (1986) Deriving phylogenetic trees from allele frequencies: a comparison of nine genetic distances. Syst Zool 35, 297-310

Ryman N, Beckman G, Bruun-Petersen G, Reuterwall C (1977) Variability of red cell enzymes and genetic implications of management policies in Scandinavian moose (Alces alces). Hereditas 85, 157-162

Ryman N, Reuterwall C, Nygren K, Nygren T (1980) Genetic variation and differentiation in Scandinavian moose (Alces alces): are large mammals monomorphic? Evolution 34, 1037-1050

Sarich VM (1977) Rates, sample sizes, and the neutrality hypothesis for electrophoresis in evolutionary studies. Nature 265, 24-28

Sheffield SR, Morgan RP II, Feldhamer GA, Harman DM (1985) Genetic variation in white-tailed deer (Odocoileus virginianus) populations in Western Maryland. $J$ Mammal 66, 243-255

Smith MH, Branan WV, Marchinton RL, Johns PE, Wooten MC (1986) Genetic and morphologic comparisons of red brocket, brown brocket and white-tailed deer. J Mammal 67, 103-111

Szederjei A (1965) Szarvas. Mezögazdasagi Kiado, 2nd edn, Budapest

Wagenknecht E (1986) Der Rothirsch. J Neumann-Neudamm, Melsungen, 2nd edn, pp 484 